\title{
THE CRUCIAL ISSUES ABOUT THE LEGALIZATION LEGISLATION ON ILLEGAL CONSTRUCTIONS IN ALBANIA. WHAT CAN WE LEARN FROM THE BALCANIC EXPERIENCE?
}

\author{
Silvana Dode \\ PhD Cand. State \\ University of Tirana \\ Lawyer. Lecturer at "Aleksander Xhuvani" \\ University, Elbasan, Albania. \\ silvana.dode@uniel.edu.al \\ silva.dode@yahoo.com
}

DOI:10.5901/mjss.2014.v5n22p395

\begin{abstract}
:
In the process of transition of the Balkan countries towards democracy, the strengthening of the "rule of law" is a key factor. The process of legalization in Albania is a clear indication that this transition has not been developed as it should have. In post-communist Albania, ranging from the 1990s to the present day the problem of illegal buildings remains a disturbing fact to which, no final solution has been found, yet. The solution that the Albanian government has given to the problem is the implementation of the system of Ownership Reform substantial part of which is the legalization of these buildings through a law of 'legalization', which makes legal, situations that were illegal up to that moment. This paper will aim to provide a solution to the question "The problems that have arisen during the legalization process in Albania. What can be done in the future by observing and taking into consideration the experience of countries with similar experiences?". Thus we will deal especially with the evaluation fact of defining how much coherent and pragmatic the policy of legalization has been and how much acceptable it is valued by all stakeholders involved in this process (unlicensed builders, former owners, state, third parties, and international actors. Which are the main obstacles that have slowed down the process of legalization up to now and how to remove or overcomere them.In conclusion it will be emphasized the positive elements by European practices especially from Balkan countries, to be taken into account. By observing in comparative ways, there will be noticed that the legalization process is not only an Albanian phenomenon but has occured in all post-communist countries due to the unconsolidated market of real property trade after 1990 and because of the fact that many properties continued to remain " without an owner', for a long time due to the excessive length of the process of restitution of property to former owners. In conclusion, it can be said that in the future, only a well developed - 20-year vision territory planning policy, would contribute to the elimination of the phenomenon of informal constructions, which are a blocked asset not only to their builders but to the albanian society as well.
\end{abstract}

Keywords: Process of legalization; Albania ; Balkan countries; ownership reforms; legalization legislation; illegal constructions.

\section{Introduction}

Since 1991, when Albania's democratic system was set up and up to 2014 on average it is estimated that 400, 000 buildings were built without permit, a very large figure considering the population of only about 3 million people.This phenomenon is visibly widespread in all the Western Balkans countries. Being mainly developing countries, in the Balkans property rights have been very uncertain, and as De Soto noted: "property rights to land and dwellings in developing nations are notoriously insecure, a fact that has helped impoverish the citizens of those nations. "(Benjamin, 2008) The widespread phenomenon of illegal buildings forced the governments of these countries to undertake the temporary legalization process. Legalization is simultaneously a consequence of a weak democracy and lack of law enforcement, but at the same time is also a necessity for a system of governance for the benefit of the citizens and an advanced economy. When people do not have a clear concept of law and the violation of the law becomes a rule, then state intervention is vital for any society because as Niebuhr.R said "Man's capacity for justice makes democracy possible, but man's inclination to injustice makes democracy necessary." The most important initiative in the Balkan countries regarding the legalization process was the signing in Vienna on September 20, 2004 of the "Vienna Declaration on Informal Settlements in South Eastern Europe", 
from four countries (Albania, Macedonia, Montenegro, Serbia) and on 17.03.2005 by Kosova. The focus of this statement was: "to commonly agree on actions that will regularize (legalize) and improve informal settlements in a sustainable way and will prevent future illegal settlements." The signature of this statement has been very important and decisive in accelerating the process of legalization in the Balkans.

The essence of the process of legalization is: "To make legal or lawful; to confirm or validate what was before void or unlawful."1 Legalization of illegal buildings "refers to the legal regulation of individual buildings or entire settlements considered "illegal" by the local authorities" (BPRI, 2014). Illegal buildings are buildings built on land legally owned by the builder or on the land of a third party, without planning permission or in excess thereof. Besides illegal isolated buildings, another phenomenon is entire settlements of illegal buildings which are a result of informal development. The latter is a social phenomenon deficient in legal form "Where people settle on land that may be owned by others or the state and build dwellings - usually sub-standard and temporary in nature. Informal development may even appear on legally owned land while it's illegality is related to zoning, planning, or building regulations. "(Potsiou, 2012)

A result of informal development are informal settlements which, according to the Vienna Declaration, point 2 are "Human settlements, which for a variety of reasons do not meet requirements for legal recognition (and have been constructed without respecting formal procedure of legal ownership, transfer of ownership as well as construction and urban planning regulations), exist in their respective countries and hamper economic development." Legalization is crucial for a society because it serves " to incorporate these structures into the social, economic and physical (infrastructure and services) fabric of the surrounding city and society. "(BPRI, 2014)

\section{Causes of illegal buildings in Albania.}

Firstly, legalization is generally due to the overall informality of a society. On its turn this informality is due to the incapability of the state to manage its territory, for the proper administration of land and to make the law applicable by all. Secondly, displacement of population and the urbanization process. "During the 1990s, as much as one third of the population of rural (mostly northern, mountainous) regions migrated to urban, peri-urban, and coastal areas in search of income generation opportunities, despite the lack of adequate housing infrastructure or public service provision."(WB, 2012). Freedom of housing and the right to move are negative freedoms, which implies the state must not interfere in the exercise of that right, but the intervention of the state during transition periods (not limiting the right to move but through helping the population and better managing the situation) affects more positively than a completely indifferent attitude, as actually happened in Albania after 1991. Thirdly, the need for better houses. During communism the majority of the population in cities lived in apartments in average $50 \mathrm{~m} 2$, where a family with 4-5 members lived. These dwellings were owned by the state and were rented for little money to residents. These flats were privatized, becoming a property of the inhabitants only in 1992 with the Law "On privatization of public housing units." Unfortunately, since then up to now a negative phenomenon has been noticed. A large number of illegal extensions have been built, this as a demonstration of the need for larger residence space. Fourthly, prolonged procedures to obtain building permits. The building permit is the main document to enable the construction of a building within the rules. During the years 1998-2009 (just the period when the majority of the illegal buildings were built) the law "On urban planning" was in power and it stipulated in Article 45: "Every natural or legal person, domestic or foreign, that will build on the territory of the Republic of Albania should be provided with building permit. This is the only legal document on the basis of which is permitted to construct." But corruption, complicated procedures and prolonged deadlines make it difficult to obtain a construction permit. According to BEEPS ${ }^{2}$ study of 2008 "29\% of firms said that informal payments were expected for construction permits, the highest for any business process in Albania; 3 times higher than SEE average."(Rontonyanni, 2011).Also as Doing Business survey in 2011 highlighted, Albania is the last in among all Balkan countries concerning the number of days it takes to get a building permit. It takes 331 days (approximately 11 months) in Albania, compared to 169 days in 146 days in Greece and Macedonia, in Montenegro 230 days and 279 days in Serbia. The procedures to obtain building permits are also quite complicated. In the study of Doing Business 2013, "Albania is the only country in SEE that does not have a clear practice on getting a construction permit" (Rama, 2013).Fifthly, there is a lack of state policies on preventing illegal constructions, especially in urban areas, where preliminary screening may be more effective. The principle that "An ounce of prevention is worth a pound of cure." applies in this case too. Legalization or demolition of illegal buildings is a pragmatic solution, but their prevention is the best solution and with the lowest cost. "Experience shows, legalization, penalties and even demolition

\footnotetext{
${ }^{1}$ www.thelawdictionary.org/legalize

2 Business Environment and Enterprise Performance Survey
} 
has not completely stopped informal development."(Un-Habitat, 2010) Sixthly, the overlong process of restitution of property to former owners, expropriated during the communist regime. This process began in 1993 and was scheduled to finish in May 2014, but has been postponed again until 30 April 2015. Due to the excessive length of this process for years it is not defined the ownership of the land of former owners, indirectly fueling the construction over them of illegal buildings from former owners who claim ownership or third persons. Restitution and compensation process affects the process of legalization. If the former owner of the property has been physically compensated or his land has been restituted before the start of the process of legalization, he is considered a legitimate owner. If the process of legalization begins, it should be terminated until a solution to the conflict in court between the former owner and illegal builder. On the other hand the process of legalization affects the conclusion of the return and compensation process. If a decision, whether the property will be returned physically or will be compensated, hasn't been made and meanwhile the process of legalization of illegal building built on his property has begun, the process of return/compensation should be suspended. There can't be made a physical return of the property to the former owner, if the legal deadline foreseen in the Law on Legalization hasn't terminated. ${ }^{1}$ The judicial cases at Albanian law courts with "property disputes" object, especially between former owners and their squatters should be treated with priority by the Albanian state. This is a demand repeated by foreign authorities. "The Courts have not been successful in resolving property disputes or enforcing property rights, potentially damaging Albania's EU integration prospects. Property disputes represent a large share of court caseloads and citizen complaints to the People's Advocate, but enforcement of court decisions in these matters remains problematic." (WB, 2012).This prolongation has led to lower investments from foreign countries. "A survey conducted in 2008 as part of the World Bank's Investment Climate Assessment found that insecure property rights and access to land were considered to be severe or very severe obstacles by over 20 Percent of firms respectively. (WB, 2012). Seventhly, housing policy for vulnerable populations (especially Rome minorities) have been missed or have not been effective after 1990.

Regarding the importance of the process of legalization, firstly it has a great importance for the economy. "Legalization has the potential to convert this dead capital into useful capital, workable capital that can make its way into the formal system." (WB, 2012).In 2010, in Albania it was estimated that there were about "400, 000 structures covering an area of 300,000 ha, at $€ 10$ billion." This is an enormous amount taking into consideration that the official GDP of Albania for 2011 is $\$ 27.78$ billion2. It is clear that legalization is connected with immovable property and buildings, which constitute an essential element of the Gross Domestic Product (GDP) of a country. As "UNECE" 3estimates that: " at least 20 percent of the Gross Domestic Product of most nations comes from land, property, and construction. "(Montealegre, 2010). Through this process, tax revenues are increased and illegal buildings are transformed into exploitable capital. For example, in Macedonia there wasn't in power a legalization law until 2011, when "Law on the Treatment of Unlawful Constructions" was passed, by the explicit declaration stated by the Macedonian government that: "The legalization process was launched in order to raise government income from property taxes."(BPRI, 2014)

Only through the process of legalization, illegal buildings can be sold and bought freely, to be mortgaged, or can be divided. Albanian Supreme Court (SCA) in the Unifying Decision No. 1, dated 24.03.2004 states that: "real estate items of whatever nature they are, land surface, the extensions of buildings with or without permission of the competent authority, on the ground registered or not, if they themselves are not registered in the records of RERO4, should not be subject to judicial division, otherwise with its decision the court would legalize illegal and unfair actions of the parties in the trial. "

Secondly, it is laid before Albania as an obligation to secure EU membership. Informal Settlements constitute in Albania "one quarter of the population and 40\% of the built up area of major cities" (Montealegre, 2010). As stated in the Vienna Declaration, point VI: "The urban, social and economic integration of informal settlements within the overall city structure will be a key factor in preparing for accession to the EU." European Union has consistently raised during the years before the Albanian government the issue to develop a comprehensive strategy in this area: "the opinion of the European Commission on Albania's application for opening accession negotiations includes the adoption of a strategy and action plan on property rights, which should cover the restitution / compensation and legalization processes, among the key priorities which Albania will need to address prior to opening accession negotiations." (European Commission, 2010) As the World Bank states :"Resolving property disputes and enforcing property rights through the courts has been problematic, damaging

\footnotetext{
${ }^{1}$ Law no. 9583, dt.17.067.2006 "Article 28/1" For the real estate, on which unlawful objects have been set up by the third parties, physical return can't be applied without the completion of legal term provided on the law of legalization ..Upon completion of the prescribed legal term for the process of legalization, there will be applied, where possible, physical return of real property, while the rest will be compensated. "

${ }^{2}$ www.cia.gov

${ }^{3}$ United Nations Economic Commission for Europe

${ }^{4}$ Real Estate Registry Office
} 
Albania's reputation with regard to the rule of law and affecting the Albania's EU integration process." (WB, 2012).

Thirdly, it is the best alternative facing other opportunities, such as the collapse of the illegal buildings. The demolition of illegal buildings would bring a greater cost to society in general. "In Croatia 1, 600 buildings were torn down in the period 2004-2007. However, this is an unusual case in democracies, creating major social and political problem, and is not an example of good practice, and is not recommended. "(Potsiou, 2012). Especially for the economy, the collapse would bring huge losses in Albania because " It is estimated that approximately 6 to 8 billion USD has been invested in informal development construction in Albania, and that 40,000 hectares of land is occupied either informally or illegally. "(Un-Habitat, 2010)

\section{Slowdown factors of the legalization process in Albania.}

The legalization process has moved very slowly in Albania. "the latest data show that from 293, 000 applications presented, only 22, 000 applications were completed, leaving hanging a whole category of citizens who have respected administrative procedures and have declared their buildings, but have not yet received an official response on their applications "(AO, 2014). According to official data of the Ministry of Justice as well, legalization has proceeded slowly "the agency 1 has implemented administrative procedures for about $80 \%$ of buildings built before the 2006 . Legalization permits are granted for 52 '000 properties. About 100, 000 informal properties were in the preparation process for technical and legal documentation. (CMD Nr.405, 2012)

There is no doubt that the corruption of the administration is a major inhibiting factor."Corruption remains a particularly serious problem and is prevalent in many areas, including law enforcement institutions. There are still serious gaps, e.g. in monitoring local government corruption." (European Commission, 2013) Corruption has really slowed the process. "The difficulties in implementing the entire legalization process have been reinforced by a lack of political stability. Widespread corruption represents a serious obstacle in this regard. " (BPRI, 2014)

Also, an inhibitory factor was the overlong process of restitution of property. The failure to pay the value of the construction plot by the illegal builder is another decisive impeding factor. "However, legalization has not been completed for about 90,000 properties, because the process requires repayment of financial obligations by the holders of informal settlements." (CMD Nr.405, 2012)

A slowdown factor has been also the lack of thorough studies which should apprehend distinguishing features of the Albanian reality. The legalization legislation should be more appropriate for the Albanian society. Even though in 2006 the Albanian government adopted an action plan for legalization2, this decision does not set a fixed date when the legalization process was supposed to finish. For the first time the "Reform in the area of property rights 2012-2020" 32013 was set as the deadline for completing the legalization process. This term not only wasn't achieved but there are still several years ahead to fully complete the process .

In the face of this situation, the EU4 has raised before the Albanian government to develop a strategy with regard to property rights in general, and particularly in relation to legalization. "The opinion of the European Commission (EC) on Albania's application for opening accession negotiations includes the adoption of a strategy and action plan on property rights, which should cover the restitution/compensation and legalization processes, among the key priorities Albania will need to address prior to opening accession negotiations. (EC, 2010). Seeing that there was a concrete solution, the EC presented the 2013 "Roadmap for 5 priorities for 2013", where one of the main priorities was to analyze the legislation for ownership within April to June 2014. Given the fact that the legalization process is crucial for the integration of Albania into the EU, especially after the Foreign Ministers Council of EU approved the granting of candidate status to Albania in June 24, 2014. "Major and systematic efforts are needed to address persisting problems in the area of property rights. Property restitution, compensation and illegal construction are issues that need to be tackled." (EC, 2013) Legal initiatives undertaken by the Albanian state concerning legalization process.

The solution the Albanian government initially gave to the illegal constructions problem was the silence, ignoring the problem and not undertaking any legal initiative. From 31 March 1991, when the first multiparty elections were held in Albania and until 2004 there was no serious attempt by the Albanian government to address the problem of illegal buildings.

\footnotetext{
${ }^{1}$ Agency for Legalization, Urbanization and Integration of Informal Areas

${ }^{2}$ CMD (Council of Ministers Decision) Nr. 397, datë 21.6.2006

${ }^{3}$ CMD Nr. 405, datë 27.6.2012

${ }^{4}$ European Union
} 
The silence of the authorities indirectly encouraged the increase of these buildings, which were "invisible" to the economy of the country.In order to give a solution to the problem, the Albanian parliament adopted initially the Law No. 9209, dated 23.03.2004 "On the legalization of extensions to the buildings" that had as a target the legalization of illegal additives in unfinished construction and completed constructions raised before the entry into force of the law. Secondly the Law no. 9404 of October 29, 2004, "On legalization and Urban Planning of Informal Zones." It's object was the legalization of illegal buildings in informal settlements (established before the entry into force of this Act) and the urbanization of these areas.Thirdly the Law No. .9482, dt.03.04.2006 "On legalization, urbanization and integration of illegal buildings." which unified in a single law the legalization of illegal buildings in formal and informal areas and unauthorized extensions in buildings constructed with a construction permit, raised prior to the entry into force of the law. The reason for adopting this law was the lack of success achieved by the two previous laws because of the lack of a serious commitment to its implementation and failing to compile a feasibility study to make the law effective based on the peculiar features of Albanian society. As the World Bank affirms, the laws passed in 2004 "had limited success due to insufficient resources and expertise at the local government level." (WB, 2012)

Summarizing the characteristics of the legalization process in Albania we can conclude firstly that in all the adopted laws the legalizing process was initiated according to the claim of the person that had built without permit, within a limited period from the entry into force of the law. Furthermore according to the three Laws the process is under the responsibility of the local authorities. ALUIZNI was created in 2006 (Agency for legalization Urbanization and Integration of Informal Zones and buildings), which is a public legal person subordinate to the Minister of Transport and Infrastructure. This institution will accept the pleas and will manage the process of legalization and will issue the legalization permit at the end of the process. But it won't remove the competences of the local authorities in this process. Under these laws the consequences if the claim wasn't made within the term, if a false declaration was made or if the person failed to complete the technical and legal documentation were the exclusion from the legalization process and demolition of the building.

It is worth to survey more thoroughly the most important problems concerning legalization procedures sanctioned by the Law 9482/2006. This law addresses these three main processes: First: The process of legalization that aims to make illegal builders, owner of the building build without permission and of the land underneath the building. This law classifies illegal constructions depending on the type of property on which they were built (a) Constructions on the property of the builder (b)Construction on the property of a third person. (C) Construction on the state property. The greatest number of illegal buildings are built on third party property: "According to ALUIZNI data, 29 percent of the identified illegal constructions were built on land belonging to the owner, 24 percent on state land, and 35 percent on land owned by another person; information was unavailable for 12 percent of cases. "(WB, 2012) Secondly: The process of the transfer of the ownership of the building plot, and" expropriation" and compensation of the owner of the building plot whereon the illegal building is constructed, in the case when the land on which the building is build belongs to a third party. Albania's Constitutional Court (CC) stated in it's decision No. 35, dated 10.10.2007 that: "Although the law(legalization law) does not mention the term" expropriation" and does not provide a formal expropriation procedure, the persons registered in the Register of Immovable Property(RIP) and compensated because of the registration of the owners of illegal buildings, will be called de facto and de jure dispossessed. "This expropriation is done in the public interest, which in this case aims at legalization, urbanization of informal settlements and their integration in the infrastructure of the entire territory1. As the ECHR2 states in the decision "Former King of Greece vs Greece", dt.23.11.2000: "the notion of public interest should be understood broadly, especially in connection with decisions to issue laws on expropriation, which take into account political, economic and social motives." The legalization motives are economic and social and related to the interest of all the society. The third process is the urbanization and infrastructure construction of informal settlements. This urbanization will be funding through the state budget. Sustainable urban management, means under paragraph IV of the Vienna Declaration (VD) that "Informal settlements be integrated in the social and economic, spatial/physical and legal framework, particularly at the local level." Not only urbanization but the whole legalization process is under the responsibility of local authorities. Albania's Constitutional Court (CC) affirms in the decision Nr.3/2009 that: "Urban planning and land management are full and exclusive powers of the local authorities and are included in the legal concept" its assignment ", according to which via the freedom and authority to give decisions, they are responsible for their implementation. Urban planning is described as a technical and political process that has to do with people's welfare, control and use of land, the design of the urban environment, as well as protecting and enriching the natural environment. The Court specifies that are specifically the local

\footnotetext{
${ }^{1}$ Article 41 of the Albanian Constitution 1998: "1. The right of private property is guaranteed; 4. Expropriations or limitations of property rights, equivalent to expropriation, are permitted only against just compensation.5For disputes over the amount of compensation may be appealed in court. "

2 Supreme Court decision, nr.179, dt.19.04.2011 www.gjykataelarte.gov.al/
} 
government bodies administers of the territory under their jurisdiction. The Court considers that, including any decision or action, that has impact and implies land use and urban composition, in the area of "urban planning" and "land management", it isn't left out of this concept the legalization process of informal areas and buildings "

\section{Trial Practice in Albania regarding the legalization process.}

At the prolonged processes of restitution of property and legalization process we can find one of the main reasons of the weak economic development of Albania for the period 1992-2014. "When property rights are secure, people can spend their time creating wealth rather than defending it. "(Benjamin, 2008).

Some of the main problematic issues regarding the legalization process that were observed by the practice of the First Instance Court in Tirana and the Supreme Court of Albania(SC) concerning the legalization process are: Firstly, the closing moment of the legalization process is the instant when the applicant obtains the legalization permit. The legalization process can't be considered complete, even if the applicant has paid the value of the construction lot. According to the Law on Legalization if the owner of the construction lot files a suit for claiming his property in the Court against the illegal construction builder, the legalization process should be suspended. The allegation of the unlawful possessor that the recovery claim must be dismissed because it was filed after the moment when the illegal builder has paid the value of the land and undersigned the "contract of sale with reservation of property" is not accepted by the Court. The Albanian Supreme Court (SC) Decision nr.274, dt.23.04.2013 asserts that "it turns out that the respondent is not yet equipped with the legalization permit which constitutes the final document which closes the legalization procedure and legitimizes the subject to record the construction in the Register of Immovable Property. "

Secondly, the legalization process should be suspended in the case of a conflict over land ownership: (a) In the case the owner proceeded with a recovery claim, whose property is occupied by illegal constructions, involved in the process of legalization, the issue is not must be drawn out of the judicial jurisdiction, but must be explored by the court. In the decision Nr.168, dt.6.03.2008 Supreme Court (SC) affirms that: "the law" On Legalization "can't stop the hearing of the ownership disputes in court. It is the duty of The Court to assess whether the plaintiffs are owners of the land they claim to be returned and if the defendants are lawful possessor thereof. "(B) The same reasoning as above was followed by the Court in cases where the third person sues negative indictment, claiming the violation of joint public facilities by the illegal building and requires suspension of the process of legalization."Plaintiff seeks judicially from ALUIZNI, the suspension of the legalizing process of the illegal construction carried out by his neighbor, as he claims this construction prevents the use of the common driveway crossing, especially in an fire emergency. The plaintiff has the right to address ALUIZNI as the competent institution in the legalization of illegal constructions, in order to protect its legitimate interests that may be affected by the decisions of this body and has the right to require a decision in favor of these interests, but the lack of exhaustion of such a road does not prevent the claimant to petition the court with the same search. "(C) Suspension of the legalization process is done even when a third person who pretends the ownership of the construction parcel files for "inheritance claim suit"1 (d) The owner, who alleges violation of his right, may raise in same trial a civil and administrative lawsuit simultaneously. The Supreme Court's decision nr.274, dt.23.04.2013 asserts that: "The owner can raise simultaneously in the same trial a denial claim (suing the illegal constructor) but also administrative lawsuit (by suing ALUIZNI) for opposing the administrative actions taken during the process of legalization. So simultaneously with the civil court process can also be considered an administrative process of reviewing the legality of administrative procedure, suspending the administrative process."(e) With regard to resolving the civil cases in which the owner of the land sues the illegal builder (where the latter claims that the building is in the process of legalization) the Supreme Court stated in Decision no.113, dt.12.02.2013 that part of the land on which no building is built should be returned to the owner. While the land on which the building without permission was constructed and the functional surface of the building, are not returned to the owner. "The court determines that it belongs to ALUIZNI to consider the request of the defendant and if the illegal building isn't legalized, at the end of legalization process its construction should be brought down and the land returned to the owner or if the defendant's building is legalized land owner (plaintiff) must be compensated."

Thirdly, it is a common phenomenon the self-declaration of people who have not actually built the building, or not including all persons who have contributed to the construction. In these cases the persons claiming to be contributors in the construction have forced ALUIZNI by Court Decision to recognize them co-owners of the building, and the selfdeclaration was found partially invalid by the Court. SC in the Decision Nr.391 Civil College, dt.18.09.2008, states: "In the

\footnotetext{
${ }^{1}$ Supreme Court Decision, nr.434, date. 11.10.2011.
} 
case object of this judgment, the plaintiff has sought judicially to be recognized as null a document with legal consequences for her. This document is the self-declaration made before the defendant ALUIZNI by petitioner's former brother in law, pretending that the unauthorized construction was constructed by him. For this declaration the plaintiff claims that is partially null, bringing legal consequences in the exercise of the right to legalization. Plaintiff also seeks to restore the violated right for a self-declaration on her honor, hereupon the legalization of the house object to judgment. Claims with a legal reason as above are classic civil suits and are examined by court jurisdiction. "

Fourth, because of the spread of illegal buildings in a large extent, the Albanian Parliament for the first time added in 2008 to the Criminal Code, the offense "illegal construction". The added article 199/a predicts that" the illegal construction of a building on its own land is punishable by fine or imprisonment up to one year. The same act committed in public or state land or the land of another, shall be punished with imprisonment from one to five years. "We see that in the first paragraph it is a criminal offense while building on the land of another is a crime.1 A serious problem present the cases where criminal charges are filed by the prosecution for the criminal offense mentioned above, while the building was in the process of legalization. So there is a need for more cooperation between all state institutions so that the process of legalizing not only to be as fast but cost much lower for all subjects participating in it.

Fifth, the decision to grant the legalization permit is an administrative act, for this reason after the legalization procedure ends, this decision can be appealed to court, by the unlawful occupier and the expropriated owner. 2

Sixthly, during the course of the legalization process the state should carry out a full check on buildings build without permission. The illegal occupier of the building should not be allowed to demolish the building for which he has applied and to construct a brand new building over the former one. In the decision of the First Instance Court of Tirana, Nr.329 dated. 26/02/2014, we find such a situation: "The defendant is resident displaced from Kukes to Paskuqan in Tirana district, since 1992. In 1993, he built a one-storey house with an area of about 130 square meter, in an area that belonged to the state. On 08.11.2006, the house was entered in the legalization process. In this building, the defendant resided until February 2013. Since it had become uninhabitable and risked his own life and that of his family, he has demolished it without proper permit and began constructing a new house. The new facility was being built by the defendant in the same area where the old building had been built and which is freely used by him for a period of about 20 years. "In this decision the defendant was found guilty of illegal construction, followed by high financial costs for the state and for the illegal builder: (1) from year 2006 to 2013 the state has invested in the legalization procedure of the first building which was destroyed by the owner of the building, due to the lack of control by the state, (2) cost of the fine that was paid by this subject (in this case around 2500 euro), (3) there is the possibility that the second building and that he constructed can be torn down by the authorities.

In the seventh, the prolonged process of legalization leads to the emergence of an informal market, where builders of illegal constructions due to the inability to sell the property through the procedure that law requires, sell the building through written agreements between them, without notarial act. 3

The eighth, according to the law and the very essence of the legalization process, it isn't recognised the right of reinstatement of the term to apply for legalization by the physical and legal person who has not been able to submit the application within the period of self-declaration assigned by the law. The SC Decision Nr.1478, dt.26.12.2007, asserts that: "the applicant society" X "(limited lianility company), which scope of activity is in the construction field has been given permission for the construction of an object, but this company has built several more floors than it was allowed. With the emergence of Law nr.9209/2004 the applicant was entitled with the right that, within a time limit specified in this law, to request and submit the necessary documentation to legalize the additional surfaces ..Under any provision of the law it isn't provided the competence of the court to reinstate the term to apply for legalization. In these conditions, we are in front of a case that should not have been presented to the court, equivalent to a claim that can't be submitted. "

Ninth, it is noted that the Court has recognized the right of one of the co-owners to divide the common parcel even if

\footnotetext{
1 The number of criminal cases relating to 'charges of committing illegal construction "in the District Court of Tirana remains low. In 2010 6 issue / issues 2011-8 / 2012-5 issues/2013-3 issues. For 2014 there were reviewed 19 issues, of which 11 were punishment decisions. http://www.gjykatatirana.gov.al/

2 With regard to the right of the owner of the land, expropriated during the legalization process, to appeal the decision of ALUIZNI, the Albanian Constitutional Court affirms in the decision Nr.35. Dt.10.10.2007: "In Article 18 of the Administrative Procedure Code it is provided that in order to protect the constitutional and legal rights of private persons, the administrative activity should be under audit by the courts, in accordance with the provisions of the Civil Procedure Code. This means that the relevant decisions of ALUIZNI can be appealed in court. The right to appeal in court is a constitutional right that is sanctioned by Article 43 of the Constitution, so as long as according to Article 4/3 of the Constitution, its provisions are directly applicable, although the law has not explicitly accepted, not denying the individual right to appeal in court for any aspect of the law, which may arise disputes between interested persons. "www.gjk.gov.al/ 3Decision of Tirana District Court, Nr.300, dt. 24/02/2014
} 
there is built over this land an illegal construction by some of the co-owners, and this building is under the legalization process. The SC concluded in Decision no 430, dt.10.12.2009, that the trial for the division of the land should continue and the case is under the judicial jurisdiction and not under the administrative one, although the building built on the land is under the legalization process.

\section{Legalization Process in Balkan Countries}

Generally speaking the dwellings built without permit in Albania, as in all countries of the Western Balkans, are buildings in a good quality and very good living conditions. "In many cases illegal construction in Europe is well built and can be considered as "affordable housing" rather than as "slums."(Un-Habitat, 2010). The main causes of illegal buildings in the western Balkan countries are different. "In Albania, for instance, the largest number of informal settlements occurred in the 1990s after the previous system collapsed; in Republika Srpska, and specifically in Prijedor, they have emerged as a result of the war, and in Macedonia the informal settlements were largely a result of the village-town migration during the 1970s."( NALAS, 2009) The legalization problem is serious across the Balkans and the figures are alarming "nearly 780, 000 structures await legalization in Serbia, 1 million in Greece, 200, 000 in both Croatia and Bosnia and Herzegovina (BiH) and 100, 000 in Montenegro."1

But what is common for all of the states is their government's attempt to give a final solution to this problem. This is noticed in the legislation passed in 2011 in Macedonia and Croatia, Kosovo adopted the law on legalization in 2013 and Montenegro in 2012. Further on we will dissect some Balkan countries specifying their similarities and differences to and between

Let's take Greece first. The beginnings of the informal structures are ancient, since the end of World War the Second. "There was a lack of affordable housing, and general social and economic conditions in Greece were bad. Between 1945 and 1966 an estimated 380, 000 informal houses were built around Athens and Thessaloniki. This is called the "first generation of informal settlements." (UN- Habitat- 2010) The first step of legalization was undertaken in 1956 by legalizing all the illegal buildings existing when "The revised General Building Code legalized." was passed. Although since 1956 several initiatives regarding the legalization legislation, yet in 2014 the illegal buildings are a problem for the Greek state. Just like in our country, "Many informal developments in unplanned areas are of reasonably good quality."( UN-Habitat, 2010). Also Greece is making serious studies and is reviewing the legal framework for the process of legalization. But still there isn't full co-operation and the administration has many difficulties in implementing in practice this process. " $A$ cadastre is crucial for monitoring the development of informal settlements. Low political commitment and administrative capacity are obstacles."(Montealegre, 2010)

Unlike Albania, legalization is a very complicated process "The planning laws and regulations are not clear to the citizens who must hire professionals to support the process." (UN-Habitat, 2010) For many years the Greek government left the legalization process treatment in the shadow." Only in 2008, in an effort to improve real estate market due to EU harmonization framework, the government started investigating procedures to legalize the planning and building violations (permit exceeds) that exist in the planned areas (like the build-up of semi-open areas of the buildings)."(Potsiou, 2012) Unlike the Albanian practice, legalization is estimated to last at least 30 years "Law allows the formalization of planning and building informalities, only for a period of 30 years. Within the 30 year period that those properties will be formalized in the non-planned areas, local authorities are expected to proceed with the compilation and implementation of the necessary city plans, otherwise owners of such properties will be asked to pay extremely high penalties in order to "buy" the necessary land and formalize again.(Potsiou\&Boulaka, 2012).

Legalization process costs are higher in Greece than in Albania." A rough analysis of the declared informal buildings shows that the majority of those declared are commercial constructions and a few expensive informal residences. This proves that so far only the wealthy owners declare their informal properties. However, the majority of the Greek owners of informal buildings cannot afford to pay fees due to severe salary reductions, increased prices, and increased income and property taxes." (Potsiou \& Boulaka, 2012) In Albania, the properties are registered after the legalization process finishes. Whereas in Greece, legalization is a very lengthy process and the registration of land, on which the illegal construction was built, is done before the legalization process. This is done for the purpose of having the allotment free in the civil circulation.

Regarding Bosnia-Herzegovina, as all Balkan countries, this state is facing the problem of illegal buildings "Between 200, 000 to 400, 000 illegal structures, inhabited by up to 1.2 million. (Monetalegre, 2010) Just as in Albania, in Bosnia the

$1 \mathrm{http}: / /$ www. setimes.com 
process of restitution of property has hampered the implementation of the legalization process. "The focus on return of property and the related application, hearing, decision, and execution process makes it difficult to establish title to many parcels, and execution of decisions by municipal governments has been slow." (USAID, 2007). The process of legalization is dependent on the fact that who is the owner of the land on which the building was constructed. The legalization process, is seen as a competence of local government bodies, which have the primary responsibility for this process. "Towns and municipalities are introducing urban plans to regulate the presence of buildings that were illegally built. If a building is allowed to remain according to the urban plan, there is a procedure for legalizing it."(BPRI, 2014). Also it is provided the offense "illegal construction" as an attempt to stop and prevent illegal constructions. "Today, new regulations criminalize informal buildings, and a program for demolishing illegal buildings is in place." (BPRI, 33) Unlike Albania, the main causes of illegal buildings have been socio-historical conditions in which Bosnia has been found: "There is also an existence of partially illegal settlements that have established themselves with the migration of large groups of people as a consequence of war (NALAS, 2009).

In the completion of the legalization process, an inhibiting factor has been the lack of ownership Registers, damaged during the war."BiH has had a framework in place for land titling and registration since the 1930s, implemented by the Austrians. Although land registers exist across $\mathrm{BiH}$ unbeatable 30 Percent of the registers were destroyed in World War II and many were not replaced." (USAID 2007).

We can see that the unlawful buildings are quite problematic even in the newest state of the Balkans, Kosovo. There has been no special law to treat the unlawful constructions issue up to 2013. Indirectly this has stimulated the increase in number of such buildings. The figures are alarming. "It was difficult for municipalities to manage this situation and as a result it has been (unofficially) estimated that the proportion of new buildings without a building permit could be as high as 50\%." (WB Kosovo, 2013) Up to 2013, it was the duty of the local government to identify and give a solution to the unlawful buildings. "Due to the lack of such a law, several municipalities over the past few years have adopted local regulations on the legalization of informal buildings. Owners who can proof land ownership and meet safety standards can apply for the legalization of their buildings "(BPRI, 2014) Only according to the new Law "On the treatment of illegal buildings" in 2013 it is finally foreseen a unique treatment in the entire territory. Every building set up before 30 August 2013 will be legalized, but it isn't estimated the social and economic cost of the buildings that were built after this date or that are still in process of construction. Efforts should be made not to make the same mistakes as the other states of the Balkan have. The latter, have postponed the legalization term many times. The new law that was approved will be in power only for 3 years from the moment it was passed. This is different from our country where differently where legalization law has no deadline for legalization, but it is the government which based on the recommendations of the European Commission, sets deadlines for this process. The adoption of a law with a strict term can be seen as an attempt to speed up the process. It will be seen with the passing of time how fruitful this will be.

As far as Macedonia is concerned, only in February 2011, in the Parliament, "the Law on the Treatment of Unlawful Constructions", was passed. It will in operation for a 5 year period. Until this moment, informal settlement were considered as illegal, and should be demolished by the authorities. The number of self-declarations of 353.800 made within 6 months from the entry into force of the law shows the gravity of the situation.

The main cause of illegal buildings has been the population shift towards urban centers and conflicts in neighboring states. It is noted that there are more illegal buildings even after the adoption of the law and the process of legalization is proceeding slowly. The Legalization law was drafted having as the main focus the vulnerable groups "The goal was to create simple and short procedures and at the same time to make as attractive as possible to the citizens. That is an example of good practice."(Potsiou, 2012) Even the people who receive social assistance will not pay any fee for this process. The legalization process is very decentralized but central authorities carry out frequent checks on the way the local authorities are operating "Given the high degree of decentralization in the implementation of the law, the Ministry of Communication and Transport imposes strict deadlines and demands quarterly reports on progress in the legalization from each municipality. "(BPRI, 2014). This practice should be followed by Albania facilitating sharply the control of this process and will boost its acceleration.

Even in Serbia the phenomenon of illegal buildings is widespread. "About 1 million illegal units nationally, approximately 500, 000 in the Belgrade metropolitan region." (Montealegre, 2010) But the process of legalization has been even slower because of the situation in which the system of properties administration system is found. "Property rights and land administration in Serbia are under stress, owing to the country's dynamic and turbulent history." (USAID 2007) Just as in Albania, the main cause of illegal buildings has been urbanization and unplanned displacement of population from rural regions. "the large number of illegal settlements in the countries of former Yugoslavia were constructed in the 1970s when 
the process of industrialization caused mass migrational movements from the villages to the towns." (NALAS, 2009) Just like our country the legalization process has not been efficient because while this process continues, there continue to be constructed buildings without permits. This is the reason the self-declaration deadline has been postponed several times. "The new law adopted on 31 October 2013 provides a 90-day deadline to submit self-declarations. But this has hindered the application procedures requiring more detailed documentations from applicants. "The previous law required more limited technical documentation in the form of photos and an expert's technical report about the structure's condition, whereas the Owners must now submit a full project for the constructed building, which must be certified by an architect." (BPRI, 2014)

Finally, regarding Montenegro, being a country that has gained independence from Serbia only 8 years ago, through the referendum of 21 May 2006, his process of legalization has been influenced by the policies of the Serbian state.There are not to be found fully accurate data about the number of illegal buildings. Official data are much lower than those which foreign studies declare. "According to the official data from the cadastre, on the territory of Montenegro there are 39.922 illegally built structures, of which the largest number is in the capital city of Podgorica, 16.430 structures. "(Potsiou, 2012) Meanwhile, a UNDP study declares their number is estimated to be almost three times the official figures." 100, 000 informal the structure in Montenegro Which is approximately one third of the total housing stock in the country."(Helleren, 2011) It is to be noted that until 2012, the process of legalization has been different in each municipality. Only in September 2012 a bill was drafted by the government. In 2014 it is still in the final stages of discussion. The prolongation of its approval shows a lack of political will. Just like our country, Montenegro is a coastal state (called "Ecological country" in its constitution).Consequently legalization is crucial for the development of tourism. Most of the illegal buildings are of a very good quality. The prolongment of the return and compensation process is one of the causes of illegal buildings. "In 2004 a Law on Restitution of ownership rights passed in Montenegro but its implementation is doubtful" (Potsiou, 2006). As in all Balkan countries, corruption is one of the main reasons that has led to difficulties in administering the land, which is prompted more by a lack of expertise by administrative bodies. Just like in our country, illegal construction is considered as a crime since 2008. "Since 2008, illegal building has been considered a crime, but prosecution has been delayed for small primary residence." (BPRI, 2014).

But unlike Albania illegal constructions are a phenomenon that emerged in the period of communism because of non adequate housing policies. Only after the declaration of independence, the causes of illegal buildings have changed: some of them are the poverty and internal migration. The legalization process is quite complicated, with not a very low cost and is highly centralized although according to constitutional principles it should be as decentralized as possible. "The planning procedure and construction permitting is being compiled in two levels (Construction permitting Responsibility is shared between the central government and the municipalities); in general it is still highly centralized, expensive and inflexible, except some special cases. "(Potsiou, 2012). The law tends to protect vulnerable groups, providing that if the illegal building is demolished, the state provides to the individual a house, if it was the only house where his family lived. "The draft law states that people living in illegally built primary housing that will be demolished due to the law, must be provided with an alternative housing solution by the municipality."(BPRI, 2014)

We can see that all Balkan states have positive elements to be considered as an example, but in general all of them are far behind in this process, and much work still remains to be done.

\section{Recommendations}

(a) The category of persons who have built property which are in the legalization process must join together in associations. This interest group needs a single voice in front of the state bodies, because at the moment is quite fragmented. 1A positive example is the joining of the former owners' interests who are united in the Association "Property on Justice.". Its field of activity focus is the protection of the interests of the former owners, who are deprived from ownership through nationalization, confiscation and in other forms by the totalitarian regime. This association is quite active in the public's eye and in its initiatives. 2 Only by being united the subjects affected by this process, they can have a stronger influence on the legislation drafting process. (B)The prevention of illegal buildings in the future. Despite the fact that the

\footnotetext{
1 In May 2014 the Roma minority submitted before the President of the Republic of Albania a petition with 40,000 signatures, asking the president not to enact changes in the Law for Legalization.

2 In 2007 this association asked the Constitutional Court to declare the law of legalization as unconstitutional, claiming that the law violates the rights of former owners. This request was rejected by the court decision no. 35. Dt. 10.10.2007.
} 
Albanian government has set this among its main priorities of judicial reform "1, from 2004 illegal constructions continue to rise." With the persistent legalization challenges, the consequence of the widespread inability to enforce the laws in the Western Balkans region (ie, authorities' failure to prevent illegal construction or evict illegal residents) is a continuation in illegal construction." (BPRI, 2014) (c) Setting realistic deadlines for the government to complete the process of legalization. The tendency of the Albanian government is to set unrealistic limits and which do not have a real possibility for implementation. For example, this deadline specified in DCM Nr.405, dt.27.06.2012 was 2013 "100\% finalization process by Aluizni of the legalization process of 270, 592 illegal construction by 2013". (d) To be facilitated the legalization process, minimization of procedures, required documentation and decrease of the cost of this process, and accelerating the whole process. The vulnerable groups must be more in focus (especially Roma), offering them free assistance during this process and facilitation for the payment. This is also the attitude the Albanian Ombudsman has had in his report of 2013 year "Recommendation for speeding and simplifying the procedures for the legalization of informal settlements, as well as urbanization and integration." (AO, 2014). (e) Better cooperation by all state agencies and stakeholders and an increase of the public awareness for the importance of this process. (f) The process of legalization, expropriation, and the restitution and compensation of property process should have a better intertwining between them. "None of these processes (first registration, legalization, restitution, or compensation) has advanced substantially in terms of-implementation, largely due to incoherence among policy initiatives in these areas." (WB, 2012) In connection with the performance of the ALUIZNI, Albanian Ombudsman in its report of 2013 stated, "the activity of this body leaves much to be desired in its functioning since 2006. There is a lack of effectiveness and cooperation of Territory Councils, County Councils, with other bodies local Government and local Real Estate Registry Office. "(AO, 2014) (g) Greater protection for the holder of the illegal buildings in the legalization process if this building will be expropriated for public interest.(i) While the construction is under the legalization process there should be greater control have to impede the subject to demolish the building that is being legalized or to construct extensions without permission. $(\mathrm{k})$ There should be paid special attention toward the urbanization and integration process, which comes after the completion the legalization process. There should be taken effective steps that immediately after the legalization process, the process of urbanization and integration can have a full legal preliminary framework applicable in practice. (I) the need for a greater decentralization of powers of the local government during the legalization process. $(\mathrm{m})$ There is a need for serious studies on the advancement of the process of the legalization which should be made before the changes on law. These changes should have as the main focus the particular characteristics of Albania. (n) Compensation of property owners over which are built illegal construction requires a concrete planning and realistic projections for its fulfillment, "the payment of compensation for expropriation due to legalization remains insufficiently funded. AKKP reports that neither ALUIZNI nor the state budget has provided the 4.5 billion Lek needed to pay the compensation called for the legalization decisions submitted by ALUIZNI. There is a risk the failure to compensate expropriated owners could cause expropriation decisions to be declared invalid. "(WB, 2012). (p) Development of a database with all the data derived during the process of legalization, starting from the self declaration phase and progress of the process. This database must be accessible by all stakeholders and researchers in relevant issues. (Q) Prosecution of illegal builders of constructions must be performed only when, at the end of the legalization process, the legalization permit is refused by a decision of ALUIZNI. (r) Low cost and simplification of the procedures to obtain a building permit. Often it is cheaper to legalize buildings than to construct a building respecting the laws in force. $(\mathrm{H}) \mathrm{A}$ full analysis is needed from the Albanian state in order to acquire the best experiences from other Balkan countries. Although the Stability Pact and the Vienna Declaration have laid the foundations of a regional cooperation, still remains much to be done in this field. A regional structure (independent of the European Union) created especially by the Balkan states, which will be focused only on solving the problem of legalization, exchange of best experiences and, creating a database of data for all Balkan states would be mitigating for all stakeholders in this process.

By the end we can say that the legalization process and its application, must be adapted to the characteristics of each country. This is very important, because: "When Countries are not able to integrate informality into the formal economy, they will be doomed to muddle along" (Soto , 2000)

\section{References:}

${ }^{1} \mathrm{CMD}$, no. 405, 2012 "Preventing of illegal new construction will be based on completion of regulatory plans and more open and more efficient procedures for the issuance of permits, including a special register in RERO office for the registration of building permits and the strengthening of control and demolishing process. ", page 18 
Alexandra Montealegre. Prague-Czech Republic, 2010 "Informal Development in the Balkan and the Caucasus: an integrative approach to improve land tenure and economic performance." (pp) 3-8

Rama, A. (2013) "Property Rights Issues in Albania. Challenges and Perspectives. "Friedrich EbertStiftung. Page 20

AO (Albanian Ombudsman) "Annual Report on the activities of the Ombudsman for the period January to December 2013", February 2014. www.avokatipopullit.gov.al/ page 150,

BEEPS, Business Environment and Enterprise Performance Survey 2008

Benjamin, K.D. (2008) http://perc.org/sites/default/files/spr08\%20Tangents.pdf

BPRI, Best Practices for Roma Integration "Regional Report on Housing Legalization, Settlement Upgrading and Social Housing for Roma in the Western Balkans" February 2014, OSCE, ODHIR.6, 8.20-53

CMD (Council of Ministers of Albania, Decision) Nr. 405, dated 27.06.2012 "On approval of cross cutting strategy" reform in the area of property rights, 2012 to 2020 "and its plan of action". 15, 18

EC (European Commission., 2010. Opinion on Albania's Application for Membership of the European Union.

European Commission (EC) Albania Progress Report 2013. Pages 10-14

https://www.cia.gov/library/publications/the-world-factbook/geos/al.html

NALAS (Network of Associations of Local Authorities of South East Europe), 2009 "The Legislation and analysis of implementation of spatial and urban planning in Albania, Kosovo, Macedonia, Moldova, Republic of Srpska and Turkey as compares to the case of Denmark." , 12.22 to 24

Potsiou \& Boulaka "Informal Development in Greece: New Legislation for Formalization, the chances for legalization and the Dead Capital", Greece, in 2012. 6, 7.8

Potsiou C. "Study on Illegally Built Objects and Illegal Development in Montenegro", January 31.2012. 21 (2), 30-47, 6188, 101-106

Soto, H. de, 2000, The Mystery of Capital, Basic Books Perseus Books Group ISBN 0465016154. Page 21

UN ECE, 2006. Country Profiles on the Housing Sector - Serbia and Montenegro

UNDP, 2010, "Regularizing property ownerships in Montenegro. Challenges,

UN-Habitat, (Informal Urban Development in Europe - Experiences from Albania and Greece Copyright @ United Nations Human Settlements Programme, 2010. Pages 7 (2), 14, 21, 2

USAID/Kosovo.2004. Property Rights Assessment (PRA).

USAID 2007 "Land tenure and property rights regional report."23, 24.39

WB (World Bank) "Final Report, National Building Energy Efficiency study for Kosovo, 2013, 126,

WB (World Bank), "Governance in the Protection of Immovable Property Rights in Albania: A Continuing Challenge" A World Bank Issue Brief Second Edition, April 2012 " pages 8-18, 32

World Bank, 2003. FY 2004-2006 Country Assistance Strategy for Macedonia (CAS).

Vienna Declaration on Informal Settlements in South-Eastern Europe (2004) http://www.stabilitypact.org/housing/f\% 20 - $\%$ 20050415_Vienna\% 20Declaration.pdf. Pages 1-4

http://www.doingbusiness.org/data

Rontonyanni Clelia (2011), "Governance in the Protection of Immovable Property Rights", 7. Helleren, L. (2011) "Formalization of property rights. A case study of Montenegro", 3 